\title{
KEMAMPUAN MERANCANG DAN MELAKSANAKAN PEMBELAJARAN SESUAI KURIKULUM 2013 MELALUI KAJI TINDAK PEMBELAJARAN
}

\author{
Made Putra \\ Ni Wayan Suniasih \\ Universitas Pendidikan Ganesha, Jl Udayana 11 Singaraja \\ e-mail :putramd3112@yahoo.co.id
}

\begin{abstract}
The Ability of Designing and Implementing Learning Process Based on Curriculum 2013 through Lesson Study. This study was aimed to describe the ability enhancement to design and implement appropriate learning process based on Curriculum 2013 in Microteaching course through lesson study of the VI (Sixth) semester students of PGSD Denpasar. The subject of this study was VI (Sixth) semester student of PGSD Denpasar as many as 43 students consist of 5 males and 38 females. This study is a classroom action research (PTK) which is designed in two action cycles. The data collection methods used in this study was the observation and recording documents method. The instrument was an assessment rubric form used to collect data of the ability to design the learning process and observation sheet used to collect the data of learning implementation ability. Data were analyzed descriptively. The results show that there is the average score enhancement of students' ability to design learning process, 68 cycles I became 78.51 cycles II and the average score of learning implementation 69.04 cycles I became 78.1 cycles II. Thus we can conclude that the implementation of lesson study can improves students' ability in designing and implementing the learning process in Microteaching course of the VI (Sixth) semester students of PGSD Denpasar.
\end{abstract}

Keywords: designing, implementing the teaching learning process, lesson study

\begin{abstract}
Abstrak: Kemampuan Merancang dan Melaksanakan Pembelajaran Sesuai Kurikulum 2013 Melalui Kaji Tindak Pembelajaran. Penelitian ini bertujuan untuk mendeskripsikan peningkatan kemampuan merancang dan melaksanakan pembelajaran sesuai kurikulum 2013 dalam mata kuliah Microteaching melalui kaji tindak pembelajaran (lesson study) mahasiswa semester VI PGSD Denpasar. Subjek penelitian adalah mahasiswa semester VIPGSD Denpasar sebanyak 43 orang yang terdiri dari 5 orang laki-laki dan 38 orang perempuan. Jenis penelitian ini adalah penelitian tindakan kelas (PTK) yang dirancang dalam dua siklus tindakan. Metode pengumpulan data yang digunakan adalah metode observasi dan pencatatan dokumen. Instrumen penelitian berupa rubrik penilaian yang digunakan untuk mengumpulkan data tentang kemampuan merancang pembelajaran, dan lembar observasi digunakan untuk mengumpulkan data kemampuan melaksanakan pembelajaran. Data dianalisis secara deskriptif. Hasil penelitian menunjukkan bahwa terjadi peningkatan skor rata-rata kemampuan mahasiswa merancang pembelajaran adalah 68 pada siklus I menjadi 78,51 pada siklus II), dan skor rata-rata melaksanakan pembelajaran adalah 69,04 pada siklus I menjadi 78,1 pada siklus II. Dengan demikian dapat disimpulkan penerapan kaji tindak pembelajaran (lesson study) dapat meningkatkan kemampuan mahasiswa dalam merancang dan melaksanakan pembelajaran pada mata kuliah Microteaching mahasiswa semester VI PGSD Denpasar.
\end{abstract}

Kata-kata Kunci: lesson study, merancang, melaksanakan pembelajaran

Penyiapan dan pembinaan calon guru yang profesional telah ditempuh dengan berbagai upaya mulai dari proses rekrutmen mahasiswa calon guru, peningkatan kualifikasi pendidikan guru, sampai dengan penyempurnaan kurikulum Pendidikan Guru Sekolah Dasar (PGSD). Mengacu 
pada kurikulum jurusan PGSD secara tegas tersirat bahwa seorang guru dipersiapkan untuk memiliki dan menguasai empat kompetensi, yakni kompetensi paedagogis, professional, sosial, dan personal (Uno, 2010:18-20). Secara khusus, penguasaan kompetensi pedagogis dan profesional tersebut ditempuh melalui penguasaan mata kuliah, baik teori maupun praktek keguruan.

Praktek keguruan diimplementasikan melalui mata kuliah microteaching dan PPL riil. Mahasiswa selama mengikuti PPL dibekali berbagai teori dan praktek untuk melatih mahasiwa dalam mempersiapkan perangkat pembelajaran serta mempraktekannya dalam kegiatan pembelajaran riil di sekolah dasar. Selama mengikuti PPL mahasiswa perlu dibina dan dibimbing secara profesional oleh dosen pembimbing dan guru pamong.

Berdasarkan hasil refleksi awal selama kegiatan microteaching dan pengalaman PPL mahasiswa tahun sebelumnya, kegiatan penyusunan rencana pelaksanaan pembelajaran (RPP) dilakukan secara individual tanpa mengikutsertakan mahasiswa lain dalam kelompoknya untuk berdiskusi menyusun RPP yang akan dipraktikkan. Demikian pula, proses pembimbingan dilakukan bersifat perseorangan dan memberikan balikan langsung kepada mahasiswa tentang hasil pengamatan pembelajaran yang dilaksanakannya. Pengamatan proses pembelajaran hanya dilakukan oleh dosen pembimbing dan guru pamong secara sendiri-sendiri tanpa melibatkan dosen, guru pamong, dan mahasiswa lain sebagai pengamat secara bersama-sama.

Proses pembimbingan seperti ini akan berdampak positif pada kemampuan dan keterampilan mahasiswa, baik dalam mendisain maupun melaksanakan pembelajaran. Masukan yang diberikan oleh dosen pembimbing terfokus pada kegiatan mahasiswa dalam mengajar, tidak berdasarkan pada aktivitas atau perilaku mahasiswa selama mengikuti pembelajaran. Mahasiswa merasa puas apabila pembelajarannya dikatakan baik dan akan merasa kecewa bila pembelajarannya dikatakan kurang baik, tanpa berdasarkan pada kegiatan mahasiswa selama proses pembelajaran berlangsung.

Proses pembimbingan dan pembinaan yang berkualitas akan dapat membantu mahasiswa lebih percaya diri dalam mengelola pembelajaran dan dapat memberikan pengalaman belajar yang lebih bermakna bagi siswa. Salah satu model pembimbingan yang dapat diterapkan sebagai pilihan dalam membina profesionalisme mahasis- wa sebagai calon guru adalah pembimbingan melalui pendampingan berbasis kaji tindak pembelajaran (lesson study). Seperti diungkapkan oleh Joharmawan (2006), lesson study adalah kegiatan merancang pembelajaran untuk meningkatkan mutu belajar siswa yang dilaksanakan oleh seorang guru berdasarkan perencanaan pembelajaran yang dirancang bersama, kemudian diobservasi oleh guru lain dan direfleksi bersama berdasarkan hasil pengamatan. Tujuan dilakukan refleksi adalah untuk menyempurnakan proses pembelajaran yang menitikberatkan pada pembahasan bagaimana siswa belajar, kapan siswa mulai bosan, bagaimana memperoleh pengetahuannya, bagaimana kerjasama siswa dalam kelompok, dan lain-lain.

Dengan demikian, lesson study merupakan cara efektif yang dapat meningkatkan kualitas mengajar guru dan kualitas belajar siswa. Selain itu, lesson study yang didesain dengan baik akan menghasilkan guru yang profesional dan inovatif. Pembinaan guru dan calon guru melalui lesson study akan memberikan dampak positif bagi guru, yakniguru dapat: (1) menentukan tujuan pembelajaran dengan baik, (2) meningkatkan pembelajaran yang bermanfaat bagi siswa, (3) menentukan tujuan jangka panjang yang akan dicapai siswa, (4) merencanakan pembelajaran yang kolaboratif, (5) mengkaji dengan teliti perilaku belajar siswa, dan (6) melakukan refleksi terhadap pembelajaran yang dilakukan oleh guru berdasarkan pandangan siswa (Lewis, 2002).

Berdasarkan latar belakang yang telah dipaparkan dapat diidentifikasi masalah, yaitu: (1) proses penyusunan RPP oleh mahasiswa kurang berkolaborasi dengan teman sekelompoknya, (2) proses pembimbingan penyusunan RPP masih bersifat perorangan dan kurang melibatkan saran atau pendapat mahasiswa lain, (3) kemampuan mahasiswa dalam menyusun rencana pembelajaran masih kurang, serta (4) kemampuan mahasiswa dalam melaksanakan pembelajaran kurang inovatif.

Berdasarkan, identifikasi masalah dan refleksi awal yang dilakukan peneliti, maka dirumuskan masalah penelitian yaitu: (1) Apakah kaji tindak pembelajaran dapat meningkatkan kemampuan mahasiswa dalam merancang pembelajaran sesuai kurikulum 2013 pada mahasiswa PPL PGSD Denpasar?, dan (2) Apakah kaji tindak pembelajaran dapat meningkatkan kemampuan mahasiswa dalam melaksanakan pembelajaran sesuai kurikulum 2013 pada mahasiswa PPL PGSD Denpasar? 
Kegiatan pembinaan untuk meningkatkan kualitas guru dalam satu kelompok mata pelajaran maupun kelompok guru kelas ditempuh model pelaksanaan melalui kaji tindak (lesson stu$d y)$. Cara ini dilakukan karena guru dalam satu kelompok dapat saling belajar tentang metode pembelajaran dalam tahap perencanaan pembelajaran, tahap pelaksanaan pembelajaran di kelas, dan juga mendiskusikan proses pembelajaran yang dilakukan berdasarkan hasil pengamatan bersama saat salah seorang guru memperaktekkan rancangan pembelajaran yang disusun bersama, dan yang lebih penting guru dapat memahami bagaimana siswa belajar.

Perubahan sikap yang diperlukan oleh seorang guru dalam melaksanakan lesson study meliputi: 1. Semangat introspeksi terhadap apa yang sudah dilakukan selama melakukan proses pembelajaran, 2. Keberanian untuk membuka diri untuk dapat menerima saran dari orang lain guna peningkatan kualitas diri, 3. Keberanian untuk mengakui kesalahan diri sendiri, 4. Keberanian untuk mengakui dan memakai ide orang lain yang baik, 5. Keberanian untuk memberikan masukan yang jujur kepada orang lain.

Lesson study merupakan siklus kegiatan kelompok guru yang bekerja sama dalam menentukan tujuan pembelajaran, melakukan research lesson, dan secara berkolaborasi mangamati, mendiskusikan dan memperbaiki pembelajajaran tersebut ( Lewis, 2002 ).

Langkah-langkah pelaksanaan lesson study mencakup tujuh kegiatan, yakni: 1. Pembentukan kelompok lesson study, 2. Penentuan focus lesson study, 3. Perencanaan lesson study, 4. Persiapan observasi, 5. pelaksanaan dan observasi pembelajaran, 6. Tanya jawab (diskusi) tentang pembelajaran yang dilaksanakan, dan 7. Refleksi dan perencanaan langkah berikutnya ( Richarson, 2004). Berdasarkan tujuh tahapan lesson study yang dipaparkan di atas,secara sederhana kegiatan lesson study dapat dsingkat menjadi kegiatan: plan, do, see, dan reflection.

Proses pembelajaran merupakan suatu sistem,dengan demikian, pencapaian standar proses untuk meningkatkan kualitas pembelajaran dapat dimulai dari menganalisis setiap komponen yang dapat membentuk dan mempengaruhi proses pembelajaran. Salah satu komponen yang selama ini dianggap sangat mempengaruhi proses pembelajaran adalah guru dan calon guru. Strategi pencapaian proses pendidikan dapat dilakukan melalui peningkatan profesional guru serta mengoptimalkan peran guru dalam proses pembelajaran.

Mengajar bukan hanya menyampaikan materi pembelajaran, akan tetapi suatu proses mengubah sikap siswa sesuai dengan tujuan yang diharapkan. Oleh sebab itu, dalam proses mengajar terdapat kegiatan membimbing siswa agar berkembang sesuai dengan tugas-tugas perkembangannya, melatih keterampilan baik keterampilan intelektual maupun keterampilan motorik sehingga siswa dapat hidup di masyarakat yang cepat berubah dan penuh persaingan, memotivasi siswa agar mereka dapat memecahkan berbagai persoalan hidupdalam masyarakat yang penuh tantangan, membentuk siswa yang memiliki kemampuan inovatif dan kreatif (Sanjaya, 2008). Oleh karena itu, seorang guru perlu memiliki kemampuan merancang dan mengimplementasikan berbagai setrategi pembelajaran yang dianggap cocok dengan minat dan bakat sesuai dengan taraf perkembangan siswa termasuk memanfaatkan berbagai sumber dan media pembelajaran untuk menjaga dan meningkatkan kualitas pembelajaran.

Kegiatan pembelajaran melibatkan berbagai setrategi/metode/model pembelajaran. Hal ini dimaksudkan bahwa suatu pembelajaran tentu diperlukan kecermatanatau kemampuan guru dalam memilih dan menetapkan siasat, cara, dan langkah-langkah yang digunakan guru dalam rangka mengakomodasi kebutuhan siswa untuk memperoleh pengalaman belajar. Jika pengalaman belajar diutamakan melakukan penemuan, maka teori yang seyogyanya digunakan guru adalah model pembelajaran inkuiri. Langkahlangkah operasionalnya hendaknya disertakan sehingga tampak jelas menunjukkan pengalaman belajar siswa dalam rangka membangun kompetensi isi, kompetensi dasar, dan indicator. Langkahlangkah operasional tersebut juga menyertakan pijakan-pijakan yang diperkirakan dapat mempermudah pengkonstruksian pengetahuan secara bermakna. Oleh sebab itu, dianjurkan agar penilaian dilakukan tidak hanya dilakukan pada akhir pembelajaran untuk menilai hasil pembelajaran saja, tetapi yang lebih penting adalah penilaian dilakukan secara terintegrasi dengan pembelajaran.

Santyasa (2009) mengemukakan bahwa yang perlu diperhatikan dalam pengembangan kegiatan pembelajaran, adalah: (1) Kegiatan pembelajaran dirancang untuk memberikan pengalaman belajaran yang melibatkan proses mental dan fisik melalui interaksi antar peserta didik, 
peserta didik dengan guru, lingkungan, dan sumber belajar lainnya dalam rangka pencapaian kompetensi; (2) pengalaman belajar dimaksud dapat terwujud melalui pendekatan pembelajaran yang bervariasi dan berpusat pada peserta didik, dan (3) pengalaman belajar memuat kecakapan hidup yang perlu dikuasai peserta didik.

Perencanaan pembelajaran dirancang dalam bentuk silabus dan rencana pelaksanaan pembelajaran (RPP) yang mengacu pada standar isi. Perencanaan pembelajaran meliputi: penyusunan RPP dan penyiapan media serta sumber belajar, perangkat penilaian dan skenario pembelajaran. RPP merupakan rencana kegiatan pembelajaran tatap muka untuk satu pertemuan atau lebih. RPP dikembangkan dari silabus untuk mengarahkan kegiatan pembelajaran siswa dalam upaya mencapai kompetensi dasar.

Dalam penyusunan RPP berdasarkan kurikulum 2013 hendaknya memperhatikan prinsipprinsip; (1) perbedaan individual siswa seperti kemampuan awal, tingkat intelektual, bakat, potensi, motivasi belajar, gaya belajar, kebutuhan khusus dan latar belakang budaya siswa, (2) partisipasi siswa, (3) berpusat pada siswa untuk mendorong semangat belajar siswa, kreatifitas, inspirasi, inovasi dan kemandirian, (4) pengembangan budaya membaca dan menulis yang dirancang untuk mengembangkan kegemaran membaca, pemahaman beragam bacaan, dan berekspresi dalam berbagai bentuk tulisan, (5) pemberian umpan balik tindak lanjut RPP memuat rancangan program pemberian umpan balik positif, penguatan, pengayaan, dan remidi, (6) penekanan pada keterkaitan dan keterpaduan kompetensi dasar, materi pembelajaran, kegiatan pembelajaran, indikator, penilaian, dan sumber belajar dalam satu keutuhan pengalaman belajar, (7) mengakomodasi pembelajaran tematik/terpadu, keterpaduan lintas mata pelajaran, lintas aspek belajar, dan keragaman budaya, (8) penerapan teknologi informasi dan komunikasi secara terintegrasi, sistematis, dan efektif sesuai dengan situasi dan kondisi (Depdikbud, 2013).

Sebagai implementasi dari rancangan yang telah disusun, ditindak lanjuti dalam bentuk pelaksanaan pembelajaran yang meliputi kegiatan pendahuluan, inti, dan penutup. Pada kegiatan pendahuluan guru menyiapkan siswa secara psikis dan fisik untuk mengikuti pembelajaran, memberi motivasi belajar siswa secara kontekstual sesuai manfaat dan aflikasi materi belajar dalam kehidupan sehari-hari, mengajukan pertanyaan yang mengaitkan pengetahuan sebelumnya dengan materi yang dipelajari, menjelaskan tujuan pembelajaran atau kompetensi dasar yang akan dicapai dan menyampaikan cakupan materi serta uraian kegiatan sesuai dengan perencanaan.

Pada kegiatan inti guru menggunakan model pembelajaran, pendekatan, metode, media, dan sumber belajar yang disesuaikan dengan karakteristik siswa sertamuatan materi. Pemilihan pendekatan tematik dan/atau tematik terpadu dan /atau saintifik/ inkuiri yang menghasilkan karya berbasis pemecahan masalah disesuaikan dengan karakteristik dan kompetensi. Pada kegiatan penutup, guru bersama siswa baik secara individu maupun kelompok melakukan refleksi untuk mengevaluasi seluruh rangkaian aktivitas pembelajaran dan hasil yang diperoleh siswa, memberikan umpan balik terhadap proses dan hasil pembelajaran, melakukan kegiatan tindak lanjut dalam bentuk pemberian tugas, dan mengimformasikan rencana kegiatan pembelajaran untuk pertemuan berikutnya.

Penilaian proses pembelajaran menggunakan pendekatan penilaian otentik yang menilai kesiapan siswa, proses dan hasil belajar secara utuh. Keterpaduan penilaian ketiga komponen tersebut akan menggambarkan kapasitas gaya dan perolehan belajar siswa atau bahkan mampu menghasilkan dampak instruksional dan dampak pengiring dari pembelajaran. Hasil penilaian otentik dapat digunakan oleh guru untuk merencanakan program perbaikan, pengayaan, atau pelayanan konseling. Selain itu, hasil penilaian otentik dapat digunakan sebagai bahan untuk memperbaiki proses pembelajaran. Instrumen yang digunakan berupa angket, observasi, catatan anekdot, dan refleksi.

\section{METODE}

Subjek penelitian ini adalah mahasiswa PGSD Denpasar semester VI yang berjumlah 43 orang. Mahasiswa perempuan sebanyak 38 orang dan laki-laki sebanyak 5 orang.

Penelitian ini adalah penelitian tindakan kelas (PTK) yang dirancang dalam dua siklus dengan mengunakan siklus model Lewis yang dimodifikasi oleh Kemis. Prosedur dalam penelitian ini terdiri atas beberapa tahap, yaitu tahap perencanaan, pelaksanaan, observasi, dan refleksi tindakan. Pada tahap perencanaan, peneliti bersama praktisi pendidikan mendiskusikan bagaimana tindakan dilaksanakan dan hal-hal apa yang perlu dipersiapkan meliputi: (a) mengidentifikasi masalah yang ditemukan pada observasi awal, 
(b) mengidentifikasi tujuan belajar siswa, (c) merencanakan desain pembelajaran, (d) menyiapkan research lesson yang akan diamati. Pada tahap pelaksanaan tindakan yang dilakukan adalah (a) menugaskan salah satu mahasiswa sebagai model untuk melaksanakan pembelajaran berdasarkan desain yang telah disusun, (b) peneliti bersama mahasiswa lain dan guru pamong mengamati proses pembelajaran yang dilaksanakan mahasiswa yang ditugaskan sebagai model, (c) pengamat mengumpulkan data tentang proses belajar, kemampuan berpikir, kerjasama, perilaku siswa selama pembelajaran berlangsung. Pada tahap observasi yang dilakukan adalah (a) pengamat mendiskusikan tentang pembelajaran yang telah dilaksanakan mahasiswadan (b) menganalisis data yang dikumpulkan pada saat pembelajaran berlangsung. Pada tahap refleksi yang dilakukan pengamat adalahmenyusun catatan sebagai masukan yang mencakup perencanaan pembelajaran, catatan tentang perilaku siswa sebagai hasil pengamatan, dan melakukan refleksi terhadap pembelajaran yang dilaksanakan oleh mahasiswa, dan (c) menggunakan hasil refleksi untuk memperbaiki perencanaan berikutnya.

Data tentang kemampuan mahasiswa merancang pembelajaran dikumpulkan menggunakan metode pencatatan dokumen dilengkapi instrumen berupa rubrik penilaian. Data kemampuan melaksanakan pembelajaran dikumpulkan dengan menggunakan metode observasi. Data yang telah terkumpul dianalisis dengan teknik deskriptif kuantitatif yakni dengan mengkonversikan skor yang diperoleh mahasiswa ke dalam pedoman konversi Penilaian Acuan Patokan (PAP) skala lima.

\section{HASIL DAN PEMBAHASAN}

\section{Hasil}

\section{Kemampuan Mahasiswa Melaksanakan Pem- belajaran}

Berdasarkan hasil observasi dan analisis secara kualitatif pada siklus I kemampuan mahasiswa melaksanakan pembelajaran sesuai kurikulum 2013 setelah mengikuti kegiatan kaji tindak pembelajaran untuk masing masing aspek kegiatan dapat dideskripsikan seperti berikut. Kegiatan pendahuluan yang meliputi apersepsi dan motivasi sudah cukup baik. Hal ini terlihat dari kegiatan yang dilakukan mahasiswa seperti mengajak siswa bernyanyi sesuai tema. Tanya jawab tentang pengalaman siswa sebelumnya sudah dila- kukan dengan baik. Namun pada informasi tentang langkah kegiatan yang dilakukan siswa belum diinfomasikan, demikian pula tujuan pembelajaran tidak disampaikan secara jelas. Pada kegiatan inti terutama aspek penguasaan materi, penggunaan strategi pembelajaran, pendekatan saintifik, dan penerapan pembelajaran tematik masih kurang. Sebagian besar mahasiswa kurang menguasai materi terutama dalam mengintegrasikan beberapa konsep.

Beberapa konsep dari muatan materi pelajaran belum terintegrasikan secara tematik terpa$\mathrm{du}$, sehingga masih terkesan mahasiswa mengajar untuk mata pelajaran tertentu. Kemampuan mahasiswa dalam menerapkan strategi pembelajaran masih kurang terutama dalam memunculkan kegiatan yang berorientasi pendekatan saintifik, sehingga belum memberikan pengalaman yang bermakna bagi siswa. Tugas kegiatan untuk mengamati hanya terbatas pada media berupa gambar dan peta saja, tidak menyiapkan media yang lebih konkrit sesuai dengan tema yang diajarkan. Demikian pula, kegiatan menanya dan mengasosiasi masih sangat kurang, begitu pula tugas kepada siswa untuk menginformasikan hasil pekerjaannya masih sangat minim hanya sifatnya perwakilan sehingga tidak semua siswa memperoleh pengalaman mengomunikasikan. Pelibatan siswa dalam kegiatan pembelajaran belum maksimal. Demikian pula penggunaan bahasa bagi mahasiswa masih terlalu cepat dan penggunaan kosa kata yang tidak efektif. Pada kegiatan penutup untuk semua aspek seperti kegiatan refleksi, penilaian, dan tindak lanjut sudah cukup baik.

Pada siklus II setelah dilakukan kegiatan diskusi melalui kaji tindak pembelajaran ternyata mengalami peningkatan untuk masing-masing aspek kegiatan. Pada kegiatan pendahuluan sudah semua aspek meningkat mencapai kategori baik. Demikian pula, pada kegiatan inti terutama penguasaan materi pembelajaran, penggunaan strategi pembelajaran, pemanfaatan sumber belajar, dan pelibatan siswa dalam kegiatan sudah maksimum dan berada pada kategori baik. Kegiatan akhir sebagai penutup pelajaran sudah mengalami peningkatan terutamakegiatan penilaian proses pembelajaran sudah dilakukan secara konsisten.

\section{Kemampun Mahasiswa Merencanakan Pem- belajaran}

Berdasarkan hasil observasi dan analisis secara kualitatif, pada siklus I kemampuan ma- 
hasiswa merancang pembelajaran mengacu pada kurikulum 2013 dapat dideskripsikan sebagai berikut. Pada aspek perumusan tujuan pembelajaran mahasiswa belum mampu memilih dan menentukan kegiatan sebagai pengalaman belajar siswa sehingga terkesan rancangan kegiatannya masih didominasi oleh guru. Demikian pula, aspek pemilihan media dan sumber pembelajaran masih kurang bervariasi, yaitu hanya mencantumkan media dan sumber belajar berupa gambar dan peta, padahal sesuai dengan materi yang dirancang, media dan sumber belajar sangat banyak dan mudah diperoleh di sekitar sekolah. Untuk aspek perumusan indikator dan pemilihan materi pembelajaran sudah cukup baik karena indikator dan materi pembelajaran sudah tercantum dalam buku siswa, hanya saja, mahasiswa harus mampu memilih materi dan indikator sesuai dengan tema yangdiajarakan. Demikian pula kemampuan mahasiswa pada aspek pemilihan metode terutama memvariasikan metode pembelajaran sudah cukup baik, namun masih terkesan lebih banyak aktivitas guru daripada kegiatan siswa. Setelah dilakukan diskusi melalui kegiatan kaji tindak pembelajaranuntuk perbaikan pada siklus II, ternyata kemampuan mahasiswa mengalami peningkatan yang cukup berarti terutama pada aspek perumusan indikator, pemilihan materi, sumber belajar, media dan metode pembelajaran yang sudah mencapai kategori baik. Namun, kemampuan mahasiswa merancang skenario pembelajaran masih berada pada kategori cukup. Hal ini disebabkan oleh pengalaman mahasiswa masih kurang dalam menyusun skenario pembelajaran dan belum mampu mengaitkan antara metode kegiatan, materi dan pengalaman belajar siswa agar selalu terkait dengan tema.

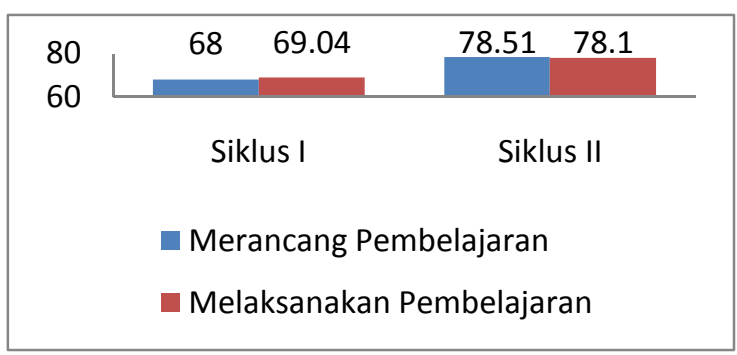

Grafik 1. Peningkatan kemampuan merancang dan melaksanakan pembelajaran

Pada siklus I kemampuan mahasiswa dalam menyusun rancangan pembelajaran (RPP) masih berada pada kategori cukup dengan besaran persentase rata-rata $68,00 \%$, kemudian pada siklus II meningkat menjadi kategori baik dengan besaran nilai rata-rata $78,51 \%$. Ini berarti terjadi peningkatan kemampuan merancang pembelajaran dari siklus I ke siklus II sebesar 10,51\%. Kemampuan mahasiswa melaksanakan pembelajaran pada siklus I masih terkategori cukup dengan besaran persentase rata-rata $69,04 \%$, dan pada siklus II mencapai kategori baik dengan besaran rata-rata $78,10 \%$. Hal ini menunjukkan terjadi peningkatan kemampuan mahasiswa melaksanakan pembelajaran dari siklus I ke siklus II sebesar $9,06 \%$.

\section{Pembahasan}

Berdasarkan hasil penelitian yang telah diuraikan di atas, dari 43 mahasiswa yang menjadi subjek penelitian ini, hasil refleksi awal menunjukkan bahwa kemampuan mahasiswa merancang dan melaksanakan pembelajaran masih terkategori rendah. Setelah dilakukan perbaikan melalui kaji tindak pembelajaran baik pada siklus I dan II terjadi peningkatan secara berkelanjutan.

Terjadinya peningkatan kemampuan mahasiswa baik dalam menyusun rencana maupun melaksanakan pembelajaran disebabkan karena keseriusan mahasiswa dalam mengikuti proses latihan untuk memperoleh pengalaman, serta efektivitas proses bimbingan selama latihan berlangsung. Proses pembimbingan yang diterapkan selama Microteaching melalui penerapan kaji tindak pembelajaran (lesson study). Pembimbingan melalui lesson study dilakukan karena mahasiswa dalam satu kelompok dapat saling belajar tentang pemilihan metode pembelajaran, baik pada tahap perencanaan, dan tahap pelaksanaan pembelajaran di kelas, dan kemudian mendiskusikan proses pembelajaran yang telah dilaksanakan berdasarkan hasil pengamatan bersama saat seorang mahasiswa mempraktikkan rancangan pembelajaran yang disusun bersama. Demikian pula terjadinya peningkatan kemampuan mahasiswa dari siklus I ke siklus II disebabkan karena mahasiswa memiliki sikap terbuka untuk diberikan masukan dan juga siap untuk memberi masukan kepada orang lain serta memiliki keberanian mengakui kekurangan. Jadi pembimbingan melalui lesson study ini merupakan cara pembinaan guru dan calon guru dalam meningkatkan kinerja melalui kelompok kegiatan sehingga dapat saling belajar dengan teman sekelompok berdasarkan hasil pengamatan dari observer. Artinya, selama proses latihan lebih menekankan pada keterbukaan, kerjasama, dan semangat merefleksi diri untuk melakukan perbaikan berdasarkan informasi dan masukan dari teman dan dosen pem- 
bimbing. Seperti diungkapkan oleh Joharmawan (2006) bahwa pembimbingan melalui lesson study memiliki keunggulan, yakni: 1) para guru memiliki semangat introspeksi terhadap apa yang telah dilakukan, 2) keberanian membuka diri untuk dapat menerima saran dari orang lain, 3) keberanian utnuk mengakui kekurangan, dan 4) keberanian mengakui dan memakai ide orang lain.

Dampak dari proses pembimbingan dari lesson study tentu bermanfaat bagi mahasiswa calon guru dalam berlatih dan meningkatkan kinerjanya sehingga kualitas pembelajaran yang dilaksanakan dapat memberikan manfaat bagi keberhasilan siswa dalam proses pembelajaran. Hal ini penting untuk dipahami oleh mahasiswa bahwa proses pembelajaran dikatakan berkualitas apabila dapat memberikan pengalaman sebanyak-banyaknya kepada siswa dan bermanfaat bagi kehidupannya.

Temuan dalam penelitian ini sejalan dengan penelitian yang dilakukan oleh Wahyuni (2013) menemukan bahwa meningkatkan hasil belajar, suasana kelas yang aktif terjadinya sha-

\section{DAFTAR RUJUKAN}

Joharmawan, Ridwan. 2005. Reformasi Sekolah melalui Lesson Study. Makalah disampaikan dalam seminar dan workshop Lesson Study di FMIPA UM 21 Juni 2005.

Lewis, Catherine C. 2002. Lesson Study: A Hand Book of Teacherled Instructional Change. Philadelphia: Research For Better School, Inc.

Merdhana, N. 2007. Buku Pedoman Pelaksanaan Program Pengalaman Lapangan. Singaraja: Undiksha.

Richardson, J. 2004. Lesson Study: Teacher Learn How to Improve Instruction. National Staff Development Council (NSDC) (Online), (http://www.nsd.org, diakses 1 Januari 2004).

Sanjaya, Wina. 2008. Strategi Pembelajaran Berorientasi Standar Proses Pendidikan. Jakarta: Kencana.

Santyasa, W. 2009. Pengembangan Perangkat Pembelajaran. Makalah disampaikan pada ring informasi dengan adanya kolaborasi antar dosen dan observer sehingga lesson study dapat diterapkan dan dilaksanakan pada semua mata kuliah.

\section{SIMPULAN}

Berdasarkan hasil penelitian dan pembahasan yang dikemukakan, dapat disimpulkan sebagai berikut. (1) Kemampuan mahasiswa merencanakan pembelajaran dapat ditingkatkan melalui kaji tndakpembelajaran pada mahasiswa semester VI PGSD Denpasar. Hal ini dapat terlihat dari peningkatan kemampuan mahasiswa dari siklus I sebesar $68,00 \%$ menjadi $78,51 \%$. (2) Kemampuan mahasiswa melaksanakan pembelajaran sesuai kurikulum 2013 dapat ditingkatkan melalui kaji tindak pembelajaran pada mahasiswa semester VI PGSD Denpasar. Hasil analisis menunjukkan terjadi peningkatan kemampuan mahasiswa dari siklus I sebesar $69,04 \%$ menjadi $78,10 \%$ pada siklus II.

Sosialisasi Kurikulum KTSP, Universitas Pendidikan Ganesha, Singaraja.

Suprapto, Edy. 2013. Implementasi Pendidikan Karakter Berbasis Lesson Study pada mata kuliah Analisis Vektor. Jurnal Edukasi Matematika dan Sains, 1(1).

Peraturan Pemerintah Nomor 32 Tahun 2013 Tentang Peubahan atas Peraturan Pemerintah No. 19 Tahun 2005 Tentang Standar Nasional Pendidikan.

Permen No. 65 Tahun 2013 Tentang Standar Proses Pendidikan Dasar dan Menengah.

Permen No. 81A Tahun 2013 Lampiran IV Tentang Implementasi Kurikulum Pedoman Umum Pembelajaran.

Wahyuni, Sri. 2013. Optimalisasi Pembelajaran Melalui Pelaksanaan Lesson Study. Jurnal Pendidikan Almuslim. 1(1).

Uno, B. Hamzah. 2010. Profesi Kependidikan (Problema, Solusi, dan Reformasi Pendidikan di Indonesia). Jakarta: Bumi Aksara. 